\title{
Antimitotic and antimutagenic action of the Hymenaea stigonocarpa bark on dividing cells
}

\author{
G. M. Santana ${ }^{a}$, M. S. M. Deus ${ }^{a}$, J. M. C. Sousa ${ }^{a}$, P. M. P. Ferreira ${ }^{b, c}$, H. B. Fernandes ${ }^{b}$ \\ and A. P. Peron ${ }^{a, d *}$
}

aDepartamento de Ciências Biológicas, Universidade Federal do Piauí - UFPI, Campus Senador Helvídio Nunes de Barros - CSHNB, Rua Cícero Duarte, 905, Junco, CEP 64607-670, Picos, PI, Brazil

bDepartamento de Biofísica e Fisiologia, Centro de Ciências da Saúde - CCS, Universidade Federal do Piauí - UFPI, Avenida Universitária, lado ímpar, Ininga, CEP 64049-550, Teresina, PI, Brazil

'Laboratório de Cancerologia Experimental - LabCancer, Programa de Pós-graduação em Ciências Farmacêuticas PPGCF, Centro de Ciências da Saúde - CCS, Universidade Federal do Piauí - UFPI, Avenida Universitária, lado ímpar, Ininga, CEP 64049-550, Teresina, PI, Brazil

${ }^{\mathrm{d}}$ Laboratório de Citogenética e Mutagênese - LaCM, Programa de Pós-graduação em Genética e Melhoramento - PPGM, Centro de Ciências Agrárias - CCA, Universidade Federal do Piauí - UFPI, Avenida Universitária, lado ímpar, Ininga, CEP 64049-550, Teresina, PI, Brazil

*e-mail: anapaulaperon@ufpi.edu.br

Received: November 6, 2014 - Accepted: February 11, 2015 - Distributed: May 31, 2016

\begin{abstract}
The objective of this study was to evaluate the action of Hymenaea stigonocarpa bark hydroalcoholic extract against a mutagenic compound using A. cepa meristematic root cells as a test system. The treatment groups were: Negative Control (NC) - distilled water; Positive Control (PC) - paracetamol at a concentration of $0.008 \mathrm{mg} / \mathrm{mL}$, Jatoba Control (JC) aqueous fraction jatobá-do-cerrado at 0.5 or 1.0 or $1.5 \mathrm{mg} / \mathrm{mL}$, and Simultaneous Treatment (ST) - jatobá-do-cerrado aqueous fraction at a concentration of 0.5 or 1.0 or $1.5 \mathrm{mg} / \mathrm{mL}$ associated with paracetamol solution at a concentration of $0.008 \mathrm{mg} / \mathrm{mL}$. All groups were analyzed at 24 and $48 \mathrm{~h}$. Five onion bulbs (five replications) were used for each treatment group. The root tips were fixed in Carnoy and slides prepared by the crush technique. Cells were analyzed throughout the cell cycle, totaling 5,000 for each treatment group at each exposure time. Mitotic indices were subjected to statistical analysis using the chi-square test $(\mathrm{p}<0.05)$. From the results it was found that the ST group, at the three concentrations, significantly potentiated the antiproliferative effect of the test system cells when compared to PC, NC and $\mathrm{TJ}$ at the three concentrations. Furthermore, the three ST concentrations significantly reduced the number of cell aberrations when compared to the number of aberrant cells obtained for the PC, demonstrating antimutagenic action on the $A$. cepa test system cells.
\end{abstract}

Keywords: jatobá-do-cerrado, cytotoxicity, protector effect.

\section{Ação antimitótica e antimutagênica do ritidoma de Hymenaea stigonocarpa Mart ex Hayne na divisão celular}

\section{Resumo}

O objetivo do presente trabalho foi avaliar a ação do extrato hidroalcólico do ritidoma de Hymenaea stigonocarpa frente a um composto mutagênico, utilizando como sistema teste as células meristemáticas de raízes de $A$. сеpa. Os grupos tratamentos avaliados foram: Controle Negativo $(\mathrm{CN})$ - água destilada; Controle Positivo $(\mathrm{CP})$ - paracetamol na concentração de $0,008 \mathrm{mg} / \mathrm{mL}$, Controle Jatobá (CJ) - fração aquosa de jatobá-do-cerrado na concentração de 0,5 ou 1,0 ou $1,5 \mathrm{mg} / \mathrm{mL}$, e Tratamento Simultâneo (TS) - fração aquosa de jatobá-do-cerrado na concentração de 0,5 ou 1,0 ou $1,5 \mathrm{mg} / \mathrm{mL}$ associada a solução de paracetamol na concentração de $0,008 \mathrm{mg} / \mathrm{mL}$. Todos os grupos foram analisados nos tempos de 24 e $48 \mathrm{~h}$. Para cada grupo tratamento cinco bulbos de cebolas (cinco repetições) foram utilizados. As radículas foram fixadas em Carnoy e as lâminas preparadas pela técnica de esmagamento. Analisaram-se células em todo ciclo celular, totalizando 5.000 para cada grupo tratamento em cada tempo de exposição. Os índices mitóticos obtidos foram submetidos à análise estatística do Qui-quadrado $(\mathrm{p}<0,05)$. A partir dos resultados verificou-se que o grupo TS, nas três concentrações, potencializou o efeito antiproliferativo significativo as células do sistema teste quando comparado ao CP, CN e TJ nas três concentrações. Ainda, o TS nas três concentrações reduziu de forma significativa o número de aberrações celulares quando comparado com o número de células aberrantes obtidas para o $\mathrm{CP}$, demonstrando ação antimutagênica as células do sistema teste $A$. cepa.

Palavras-chave: jatobá-do-cerrado, citotoxicidade, efeito protetor. 


\section{Introduction}

Leguminosae is a botanical family of large economic and medicinal importance in temperate and tropical regions around the world. Among its representatives is Hymenaea stigonocarpa (common name jatobá-do-cerrado), a species easily found in the North and Northeast regions of Brazil, especially in the open formations of the Cerrado and Caatinga biomes (Lacerda et al., 2014).

The infusion of the the bark or outer surface of the suber of this leguminous plant is widely used in folk medicine in the states of these regions for the reduction of cholesterol levels and blood glucose (Souza and Felfili, 2006), stomach pain, cramps, bronchitis and asthma relief (Orsi et al., 2012), as an anthelmintic in the treatment of depression (Valente et al., 2014) and curing urinary tract infections (Dimech et al., 2013). There are large amounts of diterpene acids, anthraquinones, minerals, tannins, pectin, flavonoids, xyloglucans and oligosaccharides in the phytochemical composition of the suber (Cartaxo et al., 2010).

In spite of its wide use in traditional medicine, there are few studies in the literature on the action of jatobá-do-cerrado on the systemic and cellular level. Among those that exist are the works done by Lacerda et al. (2014) and Silva et al. (2015), who, through the Allium cepa system, analyzed, respectively, the cytotoxic potential of the aqueous and hydroalcoholic extract of the the bark of this legume, and demonstrated a significant antiproliferative effect in the cells of the test system used. Another important result is that the concentrations tested in these two studies did not induce cell aberrations in the $A$. cepa system cells.

Many medicinal plants with cytotoxic activity have been analyzed for antimutagenic activity (WHO, 2011), as for example, other species of the genus Hymenaea, which showed antiproliferative and antimutagenic effect in cells treated with mutagenic compounds (Cartaxo et al., 2010; Sturbelle et al., 2008; Pettit et al., 2003; Abdel-Kader et al., 2002).

Resende et al. (2006) reported that chemical compounds with antimutagenic action increase the repair mechanism efficiency of the cells treated with mutagenic agents and/or cause inactivation of the mutagenic compound. As a result, they act by decreasing the cell aberration frequency. However, Przedpelska-Wasowicz and Wierzbicka (2011), cite that to prove this activity, the antimutagenic effect of a compound or an organism should be evaluated at different concentrations, exposure times and in various test systems, which can be the same employed for the study and identification of the mutagenic agents.

Bioassays with plants are considered sensitive, rapid and simple in the monitoring of toxic effects at the cellular level (Herrero et al., 2012), and the $A$. cepa root meristem cells are widely used in cytotoxicity assessment, cell aberration detection, and the assessment of mutagenic and antimutagenic activity of chemical compounds, with emphasis on studies of the effects of plant extracts (Bagatini et al., 2007; Przedpelska-Wasowicz and Wierzbicka, 2011). Furthermore, Cardoso et al. (2014), Neves et al.
(2014), Barbério et al. (2009), Sturbelle et al. (2008), and Rigonato et al. (2005) classify the $A$. cepa test system as very efficient for the initial evaluation of the cytotoxic, mutagenic and antimutagenic potential of natural products.

Thus, considering that some species of the genus Hymenaea have demonstrated cytotoxic and antimutagenic potential, that the $H$. stigonocarpa species needs to be studied further regarding its action at the cellular level, and that the $A$. cepa system is an appropriate test for the initial screening for the evaluation of antiproliferative, antimutagenic and mutagenic potential of plant extracts, the objective of the present study is to evaluate the effect of the alcoholic extract of jatobá-do-cerrado against a mutagenic compound, using $A$. cepa meristematic root cells as a test system.

\section{Material and Methods}

\subsection{Bark collection}

For this work pieces of $H$. stigonocarpa bark were collected in a medicinal garden located in the city of Teresina, Piauí State, in May 2014. The identification of the plant and sample collection were performed by Prof. Maria do Socorro Meireles de Deus, Master in Botany and professor at the Federal University of Piauí.

\subsection{Obtaining the hydroalcoholic extract}

To perform the hydroalcoholic extraction, pieces of the jatobá-do-cerrado bark were dried at room temperature for five days and then ground in a Wiley mill. The powder obtained was weighed and placed for infusion in $80 \%$ ethanol extractive solution at a 1:5 ratio in a lightless environment for $48 \mathrm{~h}$ (Coutinho and Hashimoto, 1971). The material was then stored in an amber bottle at room temperature for 11 days, and manually stirred once a day.

After this period, the material was filtered through filter paper. The obtained liquid phase was subjected to rotoevaporation under reduced pressure and a temperature of $60{ }^{\circ} \mathrm{C}$. The extract was subsequently placed in an oven for complete drying and then stored in a refrigerator. For the analyzes with $A$. cepa, part of the stored extract was diluted in distilled water to obtain the aqueous fractions.

\subsection{Concentrations and treatment groups}

For this work three concentrations, $0.5 ; 1.0$ and $1.5 \mathrm{mg} / \mathrm{mL}$ of the $H$. stigonocarpa bark alcoholic extract were established. These concentrations were defined based on work by Silva et al. (2015).

The treatment groups evaluated in this study were: Negative Control - only of distilled water; Positive Control - solution prepared with distilled water and paracetamol, a compound with proven cytotoxic, clastogenic and aneugenic action on meristematic root cells of $A$. cepa at a concentration of $0.008 \mathrm{mg} / \mathrm{mL}$ (Bessems et al., 1995); Jatoba Control - aqueous fraction of jatobá-do-cerrado at 0.5 or 1.0 or $1.5 \mathrm{mg} / \mathrm{mL}$, Simultaneous Treatment - jatobá-do-cerrado aqueous fraction at 0.5 or 1.0 or $1.5 \mathrm{mg} / \mathrm{mL}$ associated with paracetamol solution at a concentration of $0.008 \mathrm{mg} / \mathrm{mL}$. 


\subsection{Obtaining root meristem cells of A. cepa}

For conduction of the experiments, $A$. cepa bulbs were placed to root in flasks with distilled water at $25^{\circ} \mathrm{C}$, aerated constantly, until obtaining roots about $1.0 \mathrm{~cm}$ long, which were then placed in their respective treatment solutions. For analysis of each treatment group, an experimental group was established with five bulbs (five repetitions), which were evaluated at the exposure times of 24 and $48 \mathrm{~h}$. In all treatment groups at the end of each exposure time, roots were collected and fixed in 3:1 Carnoy's solution (ethanol:acetic acid) for about $24 \mathrm{~h}$.

\subsection{Slide preparation and statistical analysis}

The slides, on average 5 per bulb, were mounted according to the method proposed by the Guerra and Souza (2002) protocol, and analyzed by light microscopy at $40 \mathrm{X}$. For each bulb 1,000 cells were analyzed totaling 5,000 cells studied for each treatment group. In this analysis we observed cells in interphase, prophase, metaphase, anaphase and telophase, the presence of aneugenic effects and micronuclei. The average cell number count in each phase of the A. cepa cell cycle was calculated and the mitotic index determined. For statistical analysis we used the chi-square $\left(\chi^{2}\right)$, with $\mathrm{P}<0.05$ (BioEstat 3.0 ).

\section{Results and Discussion}

Table 1 presents the Mitotic Indices obtained for the Positive Control, Negative Control and Jatoba Control treatment groups at concentrations of $0.5 ; 1.0$ and $1.5 \mathrm{mg} / \mathrm{mL}$, and the Simultaneous Treatment at concentrations of $0.5 ; 1.0$ and $1.5 \mathrm{mg} / \mathrm{mL}$, assessed at the exposure time of 24 hours.

From the results in Table 1, it can be seen that for concentrations of 0.5 and $1.0 \mathrm{mg} / \mathrm{mL}$, the mitotic indices of their respective Simultaneous treatments were statistically different from the mitotic indices of the Positive and Negative controls. When compared with the cell division index of their respective Jatoba Control, the Simultaneous Treatment cell division rate, although lower, did not differ statistically.

For the $1.5 \mathrm{mg} / \mathrm{mL}$ concentration, the division index obtained for the Simultaneous Treatment differed from the mitotic indices of the Negative Control and their respective Jatoba Control. However, when compared to the mitotic index of the Positive Control, the cell division index of the Simultaneous Treatment was not considered different. Thus, these results demonstrated that with increasing concentration the Simultaneous Treatment enhances the antiproliferative effect. Furthermore, when comparing cell division indices among treatment groups at different concentrations, it was found that they did not differ statistically from one another.

Table 2 shows the mitotic indices obtained for the Positive Control, Negative Control, and Jatoba Control at concentrations of $0.5 ; 1.0$ and $1.5 \mathrm{mg} / \mathrm{mL}$, and Simultaneous Treatment at concentrations of $0.5 ; 1.0$ and $1.5 \mathrm{mg} / \mathrm{mL}$, measured at an exposure time of 48 hours.

In Table 2, it can be seen that at all concentrations, the Simultaneous Treatment mitotic indices were statistically similar to the cell division indices of the Positive Control and their respective Jatoba controls, demonstrating that the association of concentrations of jatobá-do-cerrado with acetaminophen, as in the $24 \mathrm{~h}$ exposure time, promoted a high antiproliferative effect no the $A$. cepa meristematic root cells, but, most markedly, since for the 48 hour exposure time at the three concentrations, the Jatoba Control cell division indices of the Simultaneous Treatment were statistically identical to those obtained for the Positive Control.

Thus, it is important to note that under the conditions examined in this study, at the two exposure times, the cytotoxicity of the hydroalcoholic extract of the jatobá-do-cerrado bark was already observed at the lowest concentration, in the Jatoba Control treatment

Table 1. Number of undifferentiated cells and those in interphase, number of cells under division, and mitotic index values obtained for the $A$. сера root cells of the treatment groups Positive Control, Negative Control and Jatoba Control at concentrations of $0.5 ; 1.0$ and $1.5 \mathrm{mg} / \mathrm{mL}$, and Simultaneous Treatment at concentrations of $0.5 ; 1.0$ and $1.5 \mathrm{mg} / \mathrm{mL}$ of the Hymenaea stigonocarpa alcoholic extract, evaluated at an exposure time of $24 \mathrm{~h}$.

\begin{tabular}{|c|c|c|c|c|}
\hline $\begin{array}{c}\text { Concentration } \\
(\mathrm{mg} / \mathrm{mL})\end{array}$ & TG $24 \mathrm{~h}$ & $\begin{array}{l}\text { Undifferentiated } \\
\text { cells / Interphase }\end{array}$ & Cells under division & MI (\%) \\
\hline \multirow{4}{*}{0.5} & $\mathrm{PC}$ & 4551 & 449 & $0.1^{\mathrm{a}}$ \\
\hline & $\mathrm{NC}$ & 3732 & 1268 & $25.4^{\mathrm{b}}$ \\
\hline & $\mathrm{JC}$ & 4811 & 189 & $3.9^{\mathrm{c}}$ \\
\hline & $\mathrm{ST}$ & 4909 & 91 & $1.8^{\mathrm{c}}$ \\
\hline \multirow[t]{2}{*}{1.0} & $\mathrm{JC}$ & 4821 & 179 & $3.6^{\mathrm{c}}$ \\
\hline & ST & 4949 & 51 & $1.2^{\mathrm{c}}$ \\
\hline \multirow[t]{2}{*}{1.5} & $\mathrm{JC}$ & 4888 & 112 & $2.2^{\mathrm{c}}$ \\
\hline & $\mathrm{ST}$ & 4950 & 50 & $1.0^{\mathrm{c}}$ \\
\hline
\end{tabular}

TG - treatment group; PC - positive control; NC - negative control; JC - jatobá control; ST - simultaneous treatment; MI - mitotic index. Different letters between the Positive Control and Negative Control differ significantly among themselves. Different letters between Treatment Groups of a same concentrations differ significantly among themselves. Different letters between the Treatment Group and the Positive and Negative Controls differ significantly among themselves. Different letters between Treatment Groups of the concentrations differ statistically among themselves. 
group, as well as in the Simultaneous Treatment. It is important to mention that the significant antiproliferative action observed for the Jatoba Control treatment groups at the three concentrations studied, at the exposure times of 24 and 48 hours corroborate the results obtained by Silva et al. (2015), i.e., that the the bark of the jatobá do cerrado presents cytotoxic potential.

Table 3 shows the total number of cell aberrations observed, total A. cepa meristematic root cells analyzed for each treatment group, Positive Control, Negative Control, Jatobá Control, at concentrations of $0.5 ; 1.0$ and $1.5 \mathrm{mg} / \mathrm{mL}$ and Simultaneous Treatment at concentrations of $0.5 ; 1.0$ and $1.5 \mathrm{mg} / \mathrm{mL}$, at an exposure time of $24 \mathrm{~h}$.

Table 4 presents the total number of cell aberrations observed, total of A. cepa meristematic root cells for each treatment group, Positive Control, Negative Control, Jatobá Control at concentrations of $0.5 ; 1.0$ and $1.5 \mathrm{mg} / \mathrm{mL}$ and
Simultaneous Treatment at concentrations of $0.5 ; 1.0$ and $1.5 \mathrm{mg} / \mathrm{mL}$, at an exposure time of $48 \mathrm{~h}$.

The results presented in Tables 3 and 4, for the 24 hour exposure time as well as for the 48 hour, showed that the number of chromosomal aberrations obtained for the Simultaneous Treatment at the three concentrations studied were drastically lower than the number of aberrations observed for the Positive Control. The number of aberrant cells observed for the Negative Control, Jatoba Control at the three concentrations and Simultaneous Treatment at three concentrations were not significant among themselves. Thus, under these study conditions, an antimutagenic effect of the concentrations $0.5 ; 1.0$ and $1.5 \mathrm{mg} / \mathrm{mL}$ of jatobádo-cerrado hydroalcoholic extract, versus paracetamol at $0.008 \mathrm{mg} / \mathrm{mL}$, may be suggested.

Dimech et al. (2013) and Orsi et al. (2012), by means of classic and gas chromatography, found that the hydroalcoholic extract of the the bark of H. stigonocarpa

Table 2. Number of undifferentiated cells and those in interphase, number of cells under division, and mitotic index values obtained for the A. cepa root cells of the treatment groups Positive Control, Negative Control and Jatoba Control at concentrations of $0.5 ; 1.0$ and $1.5 \mathrm{mg} / \mathrm{mL}$, and Simultaneous Treatment at concentrations of $0.5 ; 1.0 \mathrm{and} 1.5 \mathrm{mg} / \mathrm{mL}$ of Hymenaea stigonocarpa alcoholic extract, evaluated at an exposure time of $48 \mathrm{~h}$.

\begin{tabular}{|c|c|c|c|c|}
\hline $\begin{array}{c}\text { Concentration } \\
(\mathrm{mg} / \mathrm{mL})\end{array}$ & TG $24 \mathrm{~h}$ & $\begin{array}{l}\text { Undifferentiated } \\
\text { cells / Interphase }\end{array}$ & Cells under division & MI (\%) \\
\hline \multirow{4}{*}{0.5} & $\mathrm{PC}$ & 4551 & 449 & $0.1^{\mathrm{a}}$ \\
\hline & $\mathrm{NC}$ & 3732 & 1268 & $25.4^{\mathrm{b}}$ \\
\hline & $\mathrm{JC}$ & 4811 & 189 & $2.6^{\mathrm{a}}$ \\
\hline & ST & 4909 & 91 & $0.8^{\mathrm{a}}$ \\
\hline \multirow[t]{2}{*}{1.0} & $\mathrm{JC}$ & 4821 & 179 & $2.4^{\mathrm{a}}$ \\
\hline & ST & 4949 & 51 & $0.4^{\mathrm{a}}$ \\
\hline \multirow[t]{2}{*}{1.5} & $\mathrm{JC}$ & 4888 & 112 & $1.8^{\mathrm{a}}$ \\
\hline & ST & 4950 & 50 & $0.2^{\mathrm{a}}$ \\
\hline
\end{tabular}

TG - treatment group; PC - positive control; NC - negative control; JC - jatobá control; ST - simultaneous treatment; MI - mitotic index; Different letters between the Positive Control and Negative Control differ significantly among themselves. Different letters between Treatment Groups of a same concentrations differ significantly among themselves. Different letters between the Treatment Group and the Positive and Negative Controls differ significantly among themselves. Different letters between Treatment Groups of the concentrations differ statistically among themselves.

Table 3. Total number of cellular aberrations present in meristematic root cells of $A$. cepa of each treatment group - Positive Control, Negative Control, Jatobá Control, at concentrations of $0.5 ; 1.0$ and $1.5 \mathrm{mg} / \mathrm{mL}$, and Simultaneous Treatment at concentrations of $0.5 ; 1.0$ and $1.5 \mathrm{mg} / \mathrm{mL}$ of Hymenae stigonocarpa evaluated at an exposure time of $24 \mathrm{~h}$.

\begin{tabular}{ccccccc}
\hline $\begin{array}{c}\mathbf{C} \\
(\mathbf{m g} / \mathbf{m L})\end{array}$ & $\mathbf{T G}$ & $\mathbf{M N}$ & $\mathbf{C M}$ & $\mathbf{A B}$ & $\mathbf{T P}$ & TAC \\
\hline \multirow{2}{*}{0.5} & $\mathbf{2 4} \mathbf{~}$ & 431 & 402 & 113 & 96 & $1042^{\mathrm{a}}$ \\
& PC & 01 & 00 & 00 & 00 & $02^{\mathrm{b}}$ \\
& NC & 03 & 00 & 00 & 00 & $03^{\mathrm{b}}$ \\
1.0 & JC & 04 & 00 & 01 & 00 & $03^{\mathrm{b}}$ \\
& ST & 01 & 00 & 02 & 00 & $03^{\mathrm{b}}$ \\
1.5 & JC & 01 & 02 & 00 & 00 & $03^{\mathrm{b}}$ \\
& ST & 00 & 01 & 00 & 00 & $01^{\mathrm{b}}$ \\
\hline
\end{tabular}

$\mathrm{C}$ - concentration; TG - treatment group; $\mathrm{MN}$ - micronucleus; $\mathrm{CM}$ - colchicine metaphase; $\mathrm{AB}$ - anaphasic bridge; TP - telophasic bridge; TAC - total aberrant cells. Different letters between Treatment Groups of a same concentrations differ significantly among themselves. Different letters between the Treatment Group and the Positive and Negative Controls differ significantly among themselves. Different letters between Treatment Groups of the concentrations differ statistically among themselves. 
Table 4. Total number of cellular aberrations present in meristematic root cells of $A$. cepa for each treatment group - Positive Control, Negative Control, Jatobá Control at concentrations of $0.5 ; 1.0$ and $1.5 \mathrm{mg} / \mathrm{mL}$, and Simultaneous Treatment at concentrations of $0.5 ; 1.0$ and $1.5 \mathrm{mg} / \mathrm{mL}$ of Hymenaea stigonocarpa evaluated at an exposure time of $24 \mathrm{~h}$.

\begin{tabular}{|c|c|c|c|c|c|c|}
\hline $\begin{array}{c}\mathrm{C} \\
(\mathrm{mg} / \mathrm{mL})\end{array}$ & $\begin{array}{l}\text { TG } \\
48 \mathrm{~h} \\
\end{array}$ & MN & CM & $\mathbf{A B}$ & TP & TAC \\
\hline \multirow{4}{*}{0.5} & $\mathrm{PC}$ & 953 & 513 & 124 & 187 & $1777^{\mathrm{a}}$ \\
\hline & $\mathrm{NC}$ & 01 & 00 & 00 & 00 & $02^{\mathrm{b}}$ \\
\hline & $\mathrm{JC}$ & 01 & 00 & 00 & 00 & $01^{\mathrm{b}}$ \\
\hline & $\mathrm{ST}$ & 01 & 00 & 00 & 00 & $01^{\mathrm{b}}$ \\
\hline \multirow[t]{2}{*}{1.0} & $\mathrm{JC}$ & 01 & 00 & 00 & 00 & $01^{\mathrm{b}}$ \\
\hline & ST & 02 & 00 & 00 & 00 & $02^{\mathrm{b}}$ \\
\hline \multirow[t]{2}{*}{1.5} & $\mathrm{JC}$ & 00 & 00 & 00 & 00 & $00^{\mathrm{b}}$ \\
\hline & ST & 00 & 00 & 00 & 00 & $00^{\mathrm{b}}$ \\
\hline
\end{tabular}

$\mathrm{C}$ - concentration; TG - treatment group; $\mathrm{MN}$ - micronucleus; $\mathrm{CM}$ - colchicine metaphase; $\mathrm{AB}$ - anaphasic bridge; TP - telophasic bridge; TAC - total aberrant cells.; h: hours. Within a same concentration, different letters differ significantly. Different letters between treatment groups of the concentration and the Positive and Negative Controls differ significantly.

consists of flavonoids, especially the isoprenoids; palmitic acid, oleic acid and linoleic acid and diterpenes. Edenharder and Grünhage (2003) reported that the isoprenoid flavonoids are cytotoxic at high concentrations. Furthermore, Snijman et al. (2007) report that, besides the potential to alter the cell membrane permeability due to their astringent action, terpenes, mainly diterpenes, acting together with flavonoids, promote antimutagenic effect on cells treated with mutagenic compounds. However, despite Dimech et al. (2013) and Orsi et al. (2012) reporting the presence of these two chemicals in the alcoholic extract of the the bark of this plant, their mode of action can not yet be infered since their chemical constituents were not fractionated, measured and classified in a specific way.

As initially mentioned, few studies have been conducted on the antimutagenic and cytotoxic potential of some species of the genus Hymenaea, however, unlike jatobá-do-cerrado, there already are isolated chemical compounds from these species that promote these activities. Among the studies is that of Pettit et al. (2003), who noted that the flavonoid, palstatin, in joint action with diterpenes extracted from the leaves of Hymenaea palustre, has the potential to dramatically inhibit cell division from strains of human stomach cancer cells.

Similarly, Closa et al. (1997) found that the flavonoid astibilin and diterpenes extracted from $H$. martiana leaves significantly inhibited cell division of the liver cells of rodents treated with a clastogenic drug, $\mathrm{ClC}_{4}$, showing hepatoprotective potential. Abdel-Kader et al. (2002) found that diterpenes present in the suber of $H$. courbaril stems were cytotoxic against human ovarian cancer cells (strain A2780). The results obtained in this present study corroborate those obtained for other species of the genus Hymenaea.

It is important to mention that various antitumor drugs currently used, such as paclitaxel from the vinca alkaloids and camptothecin were isolated from medicinal plants, which makes plant bioprospecting an important resource to be exploited in the search for new therapeutic approaches against cancer (Srivastava et al., 2005). Thus, the results with $H$. stigonocarpa evidenced here suggest the need for studies with cancer cell lines and in vivo tests in rodents under different exposure times and different treatment regimens, to thus establish with propriety, the real cytotoxic and antimutagenic potential of this legume.

\section{Conclusion}

Under the conditions studied, the hydroalcoholic extract of the bark of the species H. stigonocarpa enhanced the cytotoxic effect to Allium cepa meristematic root cells when in association with a mutagenic compound, inducing a high antiproliferative effect. Furthermore, this extract had a protective effect on cells of this test system when combined with the mutagenic compound, demonstrating antimutagenic action. This work is pioneering in demonstrating the antimutagenic activity of this legume.

\section{References}

ABDEL-KADER, M., BERGER, J.M., SLEBODNICK, C., HOCH, J., MALONE, S., WISSE, J.H., WERKHOVEN, M.C., MAMBER, S. and KINGSTON, D.G., 2002. Isolation and absolute configuration of ent-Halimane diterpenoids from Hymenaea courbaril from the Suriname rain forest. Journal of Natural Products, vol. 65, no. 1, pp. 11-15. http://dx.doi.org/10.1021/ np0103261. PMid:11809056.

BAGATINI, M.D., SILVA, A.C.F. and TEDESCO, S.B., 2007. Uso do sistema teste Allium cepa como bioindicador de genotoxicidade de infusões de plantas medicinais. Revista Brasileira de Farmacognosia, vol. 17, no. 3, pp. 444-447. http:// dx.doi.org/10.1590/S0102-695X2007000300019.

BARBÉRIO, A., BARROS, L., VOLTOLINI, J.C. and MELLO, M.L., 2009. Evaluation of the cytotoxic potential of water from the river Paraíba do Sul, in Brazil, with the Allium cepa L. test. Brazilian Journal of Biology $=$ Revista Brasileira de Biologia, vol. 69 , no. 3, pp. 837-842. http://dx.doi.org/10.1590/S151969842009000400010. PMid:19802442. 
BESSEMS, J.G., GAISSEL, H.D., TE KOPPELE, J.M., VAN BENNEKOM, W.P., COMMANDEUR, J.N. and VERMEULEN, N.P., 1995. 3,5-disubstituted analogues of paracetamol synthesis, analgesic activity and cytotoxicity. Chemico-Biological Interactions, vol. 98, no. 3, pp. 237-250. http://dx.doi.org/10.1016/00092797(95)03649-0. PMid:8548862.

CARDOSO, G.H.S., DANTAS, E.B.S., SOUSA, F.R.C. and PERON, A.P. 2014. Cytotoxicity of aqueous extracts of Rosmarinus officinalis L. (Labiatae) in plant test system. Brazilian Journal of Biology = Revista Brasileira de Biologia, vol. 74, no. 4, pp. 886889. http://dx.doi.org/10.1590/1519-6984.07313. PMid:25627599.

CARTAXO, S.L., ALMEIDA, M.M.S. and ALBUQUERQUE, U.P., 2010. Medicinal plants with bioprospecting potential used in semi-arid northeastern Brazil. Journal of Ethnopharmacology, vol. 131, no. 2, pp. 326-342. http://dx.doi.org/10.1016/j.jep.2010.07.003. PMid:20621178

CLOSA, D., TORRES, M., HOTTER, G., BIOQUE, G., LÉON, O.S., GELPÍ, E. and RÓSELLO-CATAFAU, J., 1997. Prostanoids and free radicals in $\mathrm{Cl} 4 \mathrm{C}$ - induced hepatotoxicity in rats: effect astilbin. Prostaglandins, Leukotrienes, and Essential Fatty Acids, vol. 56, no. 4, pp. 331-334. http://dx.doi.org/10.1016/S09523278(97)90578-0. PMid:9150380.

COUTINHO, L.M. and HASHIMOTO, F., 1971. Sobre o efeito inibitório da germinação de sementes produzidos pro folhas de Calea cuneifólia DC. Ciência e Cultura, vol. 23, no. 6, pp. 759-764.

DIMECH, G.S., SOARES, L.A., FERREIRA, M.A., OLIVEIRA, A.G., CARVALHO, M.C. and XIMENES, E.A., 2013. Phytochemical and antibacterial investigations of the extracts and fractions from stem bark of Hymenaea stigonocarpa Mart. Ex Hayne and effect on ultrastructure of Staphylococcus aureus induced by hydroalcoholic extract. Scientific World Journal, vol. 2013, pp. 862763. PMid:24396311.

EDENHARDER, R. and GRÜNHAGE, D., 2003. Free radical scavenging abilities of flavonoids as mechanism of protection against mutagenicity induced by tert-butyl hydroperoxide or cumene hydroperoxide in Salmonella typhimurium TA102. Mutation Research, vol. 540, no. 1, pp. 1-18. http://dx.doi.org/10.1016/ S1383-5718(03)00114-1. PMid:12972054.

GUERRA, M. and SOUZA, M., 2002. Como observar os cromossomos: um guia de técnicas em citogenética vegetal, animal e humana. Ribeirão Preto: FUNPEC. 191 p.

HERRERO, O., PEREZ, J.M.M. and FERNANDEZ, P.F., 2012. Toxicological evaluation of three contaminant of emerging concern by use of A. cepa test. Mutation Research, vol. 743, no. 1, pp. 24-34.

LACERDA, L.P., MALAQUIAS, G. and PERON, A.P.N., 2014. Antiproliferative action of aqueous extracts of Hymenaea stigonocarpa Mart. (Fabaceae) on the cell cycle of Allium cepa L. Anais da Academia Brasileira de Ciências, vol. 86, no. 3, pp. 1147-1150. http://dx.doi.org/10.1590/0001-3765201420130163. PMid:25029361.

NEVES, E.S.B., FERREIRA, P.M.P., LIMA, L.H.G.M. and PERON, A.P., 2014. Action of aqueous extracts of Phyllanthus niruri L. (Euphorbiaceae) leaves on meristematic root cells of Allium cepa L. Anais da Academia Brasileira de Ciências, vol. 86 , no. 3, pp. 1131-1137. http://dx.doi.org/10.1590/00013765201420130170. PMid:25098312.

ORSI, P., BONANIN, F., SEVERI, J.A., SANTOS, C.R., VILEGAS, W., HIRUMA-LIMA, C.A. and STASI, L.C., 2012.
Hymenaea stigonocarpa Mart. Ex Hayne: a Brazilian medicinal plant with gastric and duodenal antiulcer and antidiarrheal effects in experimental rodent models. Journal of Ethnopharmacology, vol. 143, no. 1, pp. 81-90. http://dx.doi.org/10.1016/j.jep.2012.06.001. PMid:22750452.

PETTIT, G.R., MENG, Y., STEVENSON, C.A., DOUBEK, D.L., KNIGHT, J.C., CICHACZ, Z., PETTIT, R.K., CHAPUIS, J.C. and SCHMIDT, J.M., 2003. Isolation and structure of palstatin from the Amazon tree Hymenaea palustris. Journal of Natural Products, vol. 66, no. 2, pp. 259-262. http://dx.doi.org/10.1021/ np020231e. PMid:12608861.

PRZEDPELSKA-WASOWICZ, E.M. and WIERZBICKA, M., 2011. Gatting of aquaporins by heavy metals in Allium cepa L. epidermal cells. Protoplasma, vol. 248, no. 4, pp. 663-671. http://dx.doi.org/10.1007/s00709-010-0222-9. PMid:20960016.

RESENDE, F.A., ANDRADE, C.A.M.B., SILVA, M.C.F., KATO, F.H., CUNHA, W.R. and TAVARES, D.C., 2006. Antimutagenicity of ursolic acid and oleanolic acid against dosorubicin-induced clastogenic in Balb/c mice. Life Sciences, vol. 79, no. 13, pp. 12681273. http://dx.doi.org/10.1016/j.lfs.2006.03.038. PMid:16647723.

RIGONATO, J., MANTOVANI, M.S. and JORDÃO, B.Q., 2005. Mechanism of action of Chlorophyllin against Mitomycin -C mutagenicity in Allium cepa. Cytologia, vol. 69, no. 4, pp. 459495. http://dx.doi.org/10.1508/cytologia.69.459.

SILVA, L.M., CARVALHO, F.R.S., MARTINS, L.V., FERNANDES, H.B., CALOU, I.B.F. and PERON, A.P., 2015. Antiproliferative effect of the hydroalcoholic extract of Hymenaea stigonocarpa Mart. ex Hayne (Fabaceae, Caesalpinioideae) on the cell cycle of roots of Allium cepa L. Biotemas, vol. 28, no. 1, pp. 45-49.

SNIJMAN, P.W., SWANEVELDER, S., JOUBERT, E.E., GREEN, I.R. and GELDERBLOM, W.C.A., 2007. The antimutagenic activity of the major flavonoids ofrooibos (Aspalathus linearis): Some dose-response effects on mutagen activation flavonoid interactions. Mutation Research, vol. 631, no. 2, pp. 111-123. http://dx.doi.org/10.1016/j.mrgentox.2007.03.009. PMid:17537670.

SOUZA, C.D. and FELFILI, J.M., 2006. Uso de plantas medicinais na região de Alto Paraíso de Goiás, GO, Brasil. Acta Botanica Brasílica, vol. 20, no. 1, pp. 135-142. http://dx.doi.org/10.1590/ S0102-33062006000100013.

SRIVASTAVA, V., NEGI, A.S., KUMAR, J.K., GUPTA, M. and KHANUJA, S.P.S., 2005. Plant-based anticâncer molecules: A chemical and biological profile of some important leads. Bioorganic \& Medicinal Chemistry, vol. 13, no. 21, pp. 5892-5908. http:// dx.doi.org/10.1016/j.bmc.2005.05.066. PMid:16129603.

STURBELLE, R.T., PINHO, D.S., RESTANI, R.G., OLIVEIRA, G.R., GARCIAS, G.L. and MARTINO-ROTH, M.G., 2008. Avaliação da atividade mutagênica e antimutagênica de Aloe vera em teste de micronúcleo em linfócitos humanos binucleados. Revista Brasileira de Farmacognosia, vol. 20, no. 3, pp. 409-415. http://dx.doi.org/10.1590/S0102-695X2010000300019.

VALENTE, P.P., AMORIM, J.M., CASTILHO, R.O., LEITE, R.C. and RIBEIRO, M.F.B., 2014. In vitro acaricidal efficacy of plant extract from Brazilian flora and isolated substances against Rhipicephalus microplus (Acari: Ixodidae). Parasitology Research, vol. 113, no. 1, pp. 417-423. http://dx.doi.org/10.1007/ s00436-013-3670-2. PMid:24221889.

WORLD HEALTH ORGANIZATION - WHO, 2011. The world medicines situation 2011. Traditional medicines: global situation, issues and challenges. Geneva: WHO. 12 p. 